\title{
Improving Environmental Care Attitudes of Early Childhood By Utilizing Recycled Materials
}

\author{
Suharni ${ }^{{ }_{1}}$, Sri Wahyuni ${ }^{2}$, Yuli Astri ${ }^{3}$ \\ Pendidikan Guru Pendidikan Anak Usia Dini, Universitas Lancang Kuning \\ DOI: $10.31004 /$ obsesi.v5i2.783
}

\begin{abstract}
Attitude of caring for the environment can be improved since early age and influenced by the impact from environment. This research is purposely to Increase the attitude of caring for the environment Through recycle. This research was classroom action research, with subjects aged 5 to 6 years old in class B who totaling 10 children, 5 boys and 5 girls. The dependent variable from this research is attitude of caring for the environment intelligence whereas the independent variable is the use of used goods. The data collection was gathered by observation to some child on early childhood education institutions. The technique of data analysis was done through descriptive. The result showed that the attitude of caring for the child's environment intelligence could improve after getting an action. The action given was through recycling. The result showed that in pre cycle, the average percentage reached $39,53 \%$ with low criteria. And the result of the study, it can be ignored that the proportion of increasing environmental awareness among children aged 5-6 years, the average number after data analysis of pre-cycle activities is in the Low category. Then in cycle one the average number is in the Medium category, and in cycle II the figure has reached the High category.
\end{abstract}

Keywords: attitude; caring for the environment; recycle; early childhood

\begin{abstract}
Abstrak
Sikap peduli lingkungan pada anak dapat ditingkatkan sejak usia dini dan dipengaruhi oleh pelajaran yang diberikan oleh lingkungan kepada mereka. Penelitian ini bertujuan untuk meningkatkan sikap peduli lingkungan anak melalui pemanfaatan barang bekas (recycle). Penelitian ini merupakan Penelitian Tindakan Kelas, dengan subyek anak usia 5-6 tahun di kelas B yang berjumlah 10 anak, terdiri dari 5 anak laki-laki dan 5 anak perempuan. Variabel terikat dari penelitian ini adalah sikap peduli lingkungan sedangkan variabel bebas dari penelitian ini adalah pemanfaatan barang bekas (recycle). Pengumpulan data dilakukan melalui observasi. Teknik analisis data dilakukan secara deskriptif. Hasil penelitian menunjukkan bahwa sikap peduli lingkungan anak dapat meningkat setelah diberi tindakan. Adapun tindakan yang diberikan melalui kegiatan Pemanfaatan barang bekas (recycle). Berdasarkan hasil penelitian dapat diabaikan bahwa proporsi peningkatan kesadaran lingkungan pada anak usia 5-6 tahun rata-rata angka setelah analisis data kegiatan prasiklus berada pada kategori Rendah. Kemudian pada siklus satu angka rata-rata berada pada kategori sedang, dan pada siklus II sudah mencapai kategori tinggi.
\end{abstract}

Kata Kunci: sikap peduli lingkungan; barang bekas; anak usia dini

Copyright (c) 2021 Suharni, Sri Wahyuni, Yuli Astri

$\triangle$ Corresponding author:

Email Address : suharni@unilak.ac.id (Universitas Lancang Kuning, Suharni)

Received 21 September 2020, Accepted 11 January 2021, Published 10 February 2021 


\section{INTRODUCTION}

Attitudes and human behavior that will determine the good and bad conditions of an environment. The surrounding environment, whether in the form of living things such as animals and plants or inanimate objects, must be preserved. If the surrounding environment is not maintained, it is likely to bring harm to humans, on the other hand, if the environment is maintained, it can provide welfare for humans, (Triwahyuni et al., 2016). The educational environment, apart from having to be clean, tidy, must also be maintained in its beauty. Therefore, cleanliness is only related to the sensitivity and willingness of people who are responsible for the environment, (Hairiah \& Suprayogo, 2008). The child's ignorance of the cleanliness of the school environment results in an uncomfortable and unsightly environment. Overcoming problems that occur requires children's care for the environment. Children's concern for the environment is needed in order to create a comfortable atmosphere, so that the teaching and learning process will also run more conducive. Based on opinion (Purwanto, 2012) Environmental sustainability is a sensitive issue lately due to increased global warming, erratic weather, disturbed ecosystems, the emergence of diseases, and so on. Garbage, the beginning of environmental damage in the air, water, and soil. All alternative pathways to protect the environment will be in vain if it is not balanced with an attitude of caring for the environment.

At this time it is necessary to have environmental management aimed at building public health. Especially the younger generation such as early childhood so that they can be integrated with activities using used goods at school and can be monitored directly by the teacher. This is in accordance with Law no. 23 of 1992 concerning health that "school health is held to improve the ability of students to live healthy in a healthy environment, so that students can learn to grow and develop harmoniously and optimally into quality human resources" (Depkes RI \& RI, 2013). One of the efforts to overcome this problem is by providing fostering a healthy school environment. According to (Depkes RI, 2018) Fostering a healthy school environment is a combination of educational efforts and health efforts consisting of physical and mental (psychic) environments. The physical environment of the school consists of the school and its environment, while the mental environment (psychic) concerns awareness to get used to living a healthy and clean life and maintaining the cleanliness of the school environment (Astini et al., 2017).

From the opinions of the experts above, the objectives of early childhood education can be gathered to develop all aspects of child development. Early childhood development includes physical, motor, cognitive, language, emotional and social development. The development of each child is different depending on the environment where the child lives and the care of the parents. Attitudes and human behavior will determine the good and bad conditions of an environment. If the surrounding environment is not maintained, it is likely to bring harm to humans, on the contrary, if the environment is maintained, it can provide welfare for humans. By developing a healthy school environment, it can improve the ability of students to live in a healthy environment. Based on observations made by researchers, researchers found problems regarding the caring attitude of children aged 5-6 years at Early childhood education institution. The problem is that of the 10 children the researchers observed, only 2 were in the good category, 3 were in the moderate category and 5 children lacked a caring attitude towards the environment such as letting trash scattered in the classroom, wilted plants, and scattered toys. In addition, due to the lack of creativity of the teacher in carrying out activities in learning to develop a caring attitude for children so that the child's environmental care attitude becomes less. In addition, the phenomenon that occurs in the field is that the presence of teachers at Early childhood education institution never applies mutual cooperation. So the teacher must be more able to do interesting learning activities. So that it can lead to a caring attitude towards the environment for children such as utilizing used goods (recycle). 
Based on the problems mentioned, need to be carried out research on improving caring attitude child's environment through the utilization of used goods (recycle), with t Objective research is to determine the increase caring attitude child's environment through the use of second-hand goods (recycle) and u ntuk know the efforts made to improve the attitude care for the environment of children through the use of used goods (recycle) in class B TK Arafah.

\section{METHODOLOGY}

This research uses collaborative action research, where the researcher acts as the executor of the action and the teacher acts to observe the process of the action. This action research aims to improve environmental care attitudes in group B TK Arafah. Action research (PTK) consists of 4 activities carried out in a repetitive cycle of the main activities in the cycle, namely: planning, action, observation and reflection. This is done by using a pre-cycle and followed by carrying out 2 cycles. The first cycle the result of the action on 2 meetings and followed by the result of second actions cycle of 2 meetings. more details can be seen in table 1 and 2.

Table 1: Cycle I Activity Plans

\begin{tabular}{llll}
\hline \multicolumn{1}{c}{ Time } & \multicolumn{1}{c}{ Activities } & \multicolumn{1}{c}{ Tools and Materials } & \multicolumn{1}{c}{ Data Collection Tools } \\
\hline $\begin{array}{l}\text { Meetin } \\
\text { g1 }\end{array}$ & $\begin{array}{l}\text { - Crumple - squeeze } \\
\text { the HVS paper into a } \\
\text { ball / round }\end{array}$ & - HVS paper, glue, scissors & $\begin{array}{l}\text { Observation and } \\
\text { Documentation Sheet }\end{array}$ \\
\hline $\begin{array}{l}\text { Meetin } \\
\text { g } 2\end{array}$ & $\begin{array}{l}\text { - Demonstrating } \\
\text { organic waste } \\
\text { - Make clothes from } \\
\text { plastic bags }\end{array}$ & $\begin{array}{l}\text {-Trash cans, trash pictures- bags } \\
\text { of plastic, scissors, glue, and } \\
\text { paper origami }\end{array}$ & $\begin{array}{l}\text { Observation and } \\
\text { Documentation Sheet }\end{array}$ \\
\hline
\end{tabular}

Table 2: Cycle 2 Activity Plans

\begin{tabular}{|c|c|c|c|}
\hline Time & Activities & Tools and Materials & Data Collection \\
\hline Meeting 1 & $\begin{array}{l}\text { - Demonstrating inorganic } \\
\text { waste } \\
\text { - Make a bag from a plastic } \\
\text { bag }\end{array}$ & $\begin{array}{l}\text { - Trash can } \\
\text { - Plastic bags, origami paper, glue, } \\
\text { scissors, plastic rope }\end{array}$ & $\begin{array}{l}\text { Observation and } \\
\text { Documentation } \\
\text { Sheet }\end{array}$ \\
\hline Meeting 2 & $\begin{array}{l}\text { - The child made a flower pot } \\
\text { - Watering the plants }\end{array}$ & $\begin{array}{l}\text { - Plastic bottles } \\
\text { - Dipper, water }\end{array}$ & $\begin{array}{l}\text { Observation and } \\
\text { Documentation } \\
\text { Sheet }\end{array}$ \\
\hline
\end{tabular}

Action research implemented in the first semester of 2019/2020 academic year in July at TK Arafah. In preparation for writing learning improvement reports, research activities began with the preparation of planning for improvement of learning activities, compiling research instruments, collecting data, determining the discussion of problems to reporting research results. The location of this research was conducted in class B at TK Arafah, which is located at Jalan Kayangan N0. 58, Limbungan Baru, Rumbai Pesisir District, Pekanbaru City. Researchers chose TK Arafah as the research site. This research activity was carried out in group B at Arafah Kindergarten with 10 children consisting of 5 girls and 5 boys.

Parameter study this includes analysis of the attitude of caring neighborhood children to see pesentase result of learning of students with class understand the utilization of utilizing recycled materials with no understanding. Equipment collecting the data the study is guideline observation and technical analysis of the data using the formula, to see an increase in the attitude of care environments of children in a kindergarten class B Rafah Tassel coast through the utilization of utilizing recycled materials, namely the formula according to ratings 
(Purwanto, 2012). The explanation of assessment using the assessment criteria by Suharsimi (2010) the percentages.

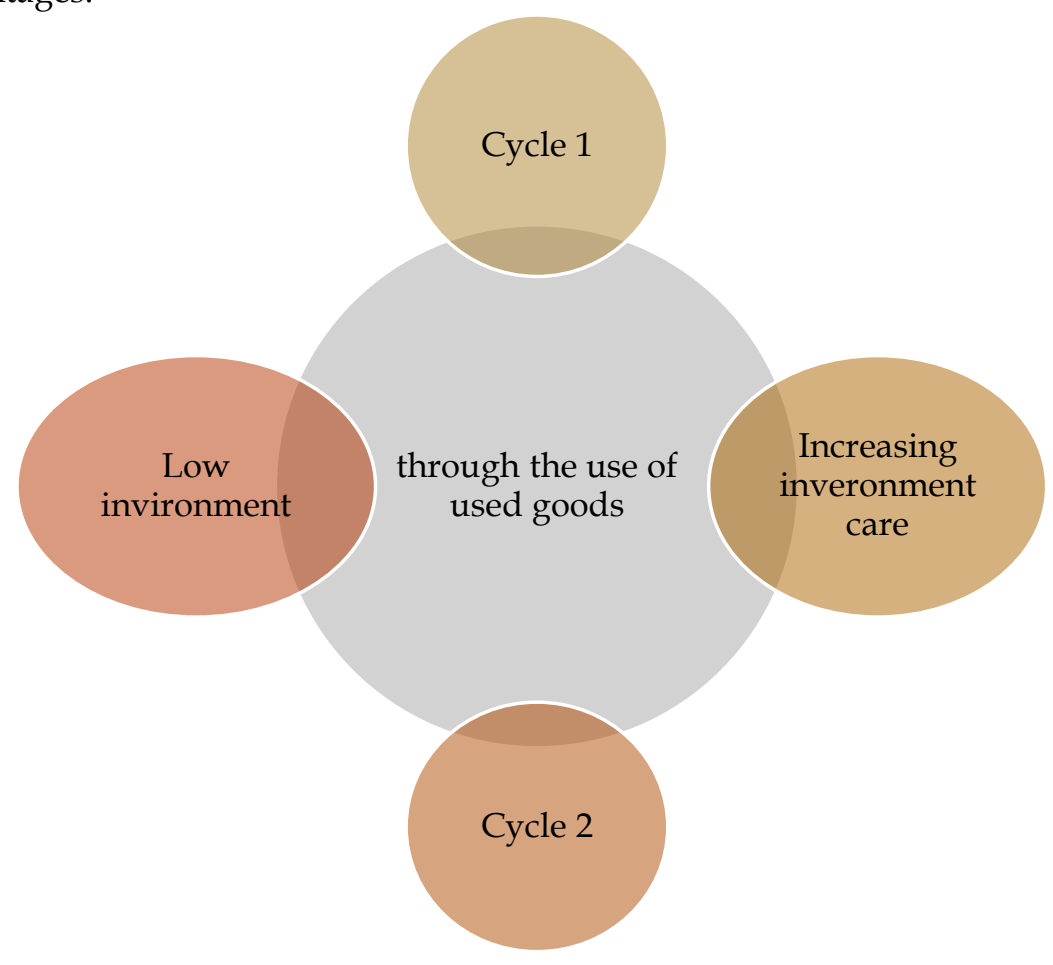

Figure 1. Research framework

\section{RESULT AND DISCUSSION}

Analysis of data on research efforts to improve children's environmental care attitudes in class B of TK Arafah through the use of used goods (recycle), can be seen from the results of the recapitulation of data on improving children's environmental care attitudes starting from initial data or pre-cycle, cycle I and cycle II.

Table 3 : Attitudes of Caring for the Environment of Children in Class B Recapitulation Pre Cycle, Cycle I, Cycle II

\begin{tabular}{|c|c|c|c|c|}
\hline No. & Indicator & Pre Cycle & Cycle 1 & Cycle 2 \\
\hline 1 & Children throw garbage in its place & 47.5 & 70 & 88.75 \\
\hline 2 & Child watering the plants & 42.5 & 57.5 & 83.75 \\
\hline 3 & Children can demonstrate organic waste & 35 & 52.5 & 72.5 \\
\hline 4 & Children can demonstrate inorganic waste & 35 & 52.5 & 72.5 \\
\hline 5 & $\begin{array}{l}\text { Children can make works of organic and inorganic } \\
\text { waste }\end{array}$ & 30 & 45 & 70 \\
\hline 6 & $\begin{array}{l}\text { Children can look after and tidy up play } \\
\text { equipment after playing }\end{array}$ & 47.5 & 70 & 91.25 \\
\hline \multirow{2}{*}{\multicolumn{2}{|c|}{$\begin{array}{c}\text { total } \\
\text { Average }\end{array}$}} & 237.5 & 347.5 & 478.75 \\
\hline & & 39.58 & 57.92 & 79.79 \\
\hline
\end{tabular}

Based on the table above, it can be explained that an increase in environmental care through the use of used goods (recycle) in the pre-cycle, the average percentage value reaches $39.58 \%$ with the criteria of Low (L), in cycle 1 the average percentage value reaches $57.92 . \%$ criteria Moderate $(\mathrm{M})$ and increased in the second cycle of $79.79 \%$ with criteria High $(\mathrm{H})$. From the comparison table for the improvement of children's environmental care attitudes in class B kindergarten Arafah Rumbai in the pre-cycle, cycle I and cycle II, it can be clarified with the the figure 2. 


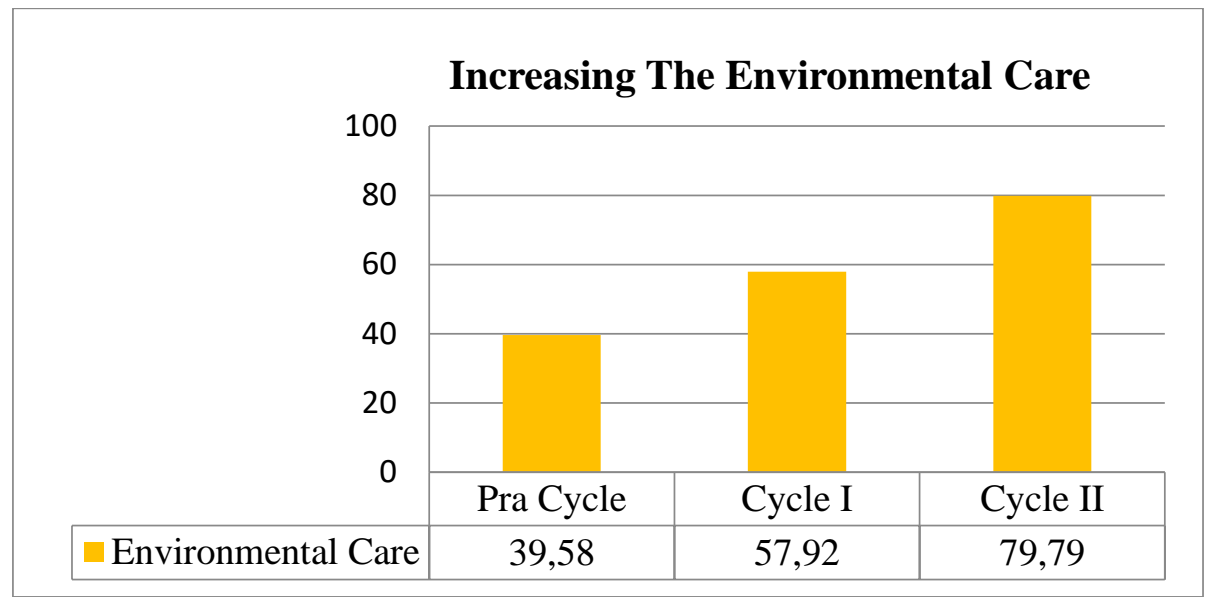

Figure 2. Improving Pre-Cycle Environmental Care Attitudes, Cycle I, Cycle II

Based on the picture and comparison table above, it can be concluded that there has been an increase in the environmental care attitude of children in class B of Arafah Rumbai Pesisir Kindergarten during the implementation of research actions in pre-cycle, cycle I and cycle II. In the pre-cycle the children's environmental care attitude was still low with Low (L) criteria, after the researcher carried out the action in cycle I the child's environmental care attitude began to experience a high enough increase with the assessment criteria Moderate (M) but the percentage had not reached the standard, so the researcher continued action to the second cycle, very satisfactory results obtained in this second cycle where the attitude of care environments of children have increased with the assessment criteria High $(\mathrm{H})$.

Improving Children's Environmental Care Attitudes through the Use of Used Goods (recycle) by recycling which is carried out in 2 cycles, namely cycle I and cycle 2 as in the cycle there are 2 meetings each meeting with different activities. The large percentage of increase can be from observations made at the pre-cycle stage which has an average number of $39.58 \%$ in the Low (L) category. In the first cycle, the average figure reached $57.92 \%$ in the Medium category (S), and in the second cycle activity an average of $79.79 \%$ was in the High category (H). According to (Yaumi, 2014) suggests that the care environment is the attitude and actions that form to prevent damage to the natural environment of the natural surroundings, and develop efforts - efforts to repair the damage to nature that is already happening.

Furthermore, the results of research (Purwanti, 2017)The pattern of school education moves and develops in accordance with the development of technological science which not only teaches cognitive aspects (knowledge) but also affective aspects (attitudes) and psychomotor aspects (behavior / habits). With regard to affective attitudes, the government has established character education. One of the characters developed is caring for the environment.

An attitude of caring for the environment must be fostered because it cannot arise by itself, such as the view of (Hamzah, 2013). Environment and humans are essentially an inseparable unit between the two of which will mutually influence each other's existence. Environmental conditions will be determined by human behavior and vice versa environmental conditions will affect human life. Therefore, caring behavior and environmentally friendly attitude is an inevitable imperative. However, caring behavior and environmentally friendly attitudes do not manifest themselves, but require knowledge, coaching and maintenance

There are many ways to improve a caring attitude towards the environment, one of which is by improving the learning process. One of them is using one of the ways to develop creativity (Septianingsih et al., 2017), namely using used materials. the media used is used aqua bottles as a medium in training creative arts from ideas that children have to simple ones in accordance with the characteristics of early childhood. ". 
Educational props are designed with attention to the level of safety and security of children, for example when using paint, the paint used is non-toxic and does not peel easily, if the tools are angled then the corners of the toys are not sharp or must be blunt so as not to endanger the child. Educational props are also designed to be simple and lightweight so that they are easy to carry and carry by children. Educational aids also encourage children to be active and constructive or produce something, different from watching TV or listening to the radio, children only passively see and listen. With APE, children can imagine and be creative in producing something, for example children playing Lego or building blocks.

Meanwhile, according to (Ahmad Susanto, 2011) that concern the environment expressed attitudes common to the quality of the environment which is manifested in the willingness of ourselves alone to declare the action - action that can improve and maintain the quality of the environment in any behavior that is associated with the environment. According to (Ngah \& Salleh, 2015) which states that a child should be in the process of sorting the garbage taken directly not only through page assessment (Lembar Kerja Siswa) were given alone. Due to involve children regard it more provide experience directly to the child, so the child is more easily accept and can hit the child from the only through words - words. The use of used goods (recycled) in addition to increasing children's caring attitudes towards the environment can also increase children's creativity. According to (Wahyuni \& Reswita, 2020) that the knowledge and skills of teachers in making educational game equipment after socialization have increased. This is reflected in the increase in the percentage of teachers' knowledge and skills in making educational play tools from natural raw materials. Based on the opinions it can in words right that an increase in the attitude of care environments of children can be increased in accordance with the expectations when it conducted activities in pre- cycle.

Application of attitudes matter of environmental children through the use of goods ex (recycle) from before do action cycle 1, cycle II there is an increase quite significantly. The benefits of recycling the children can learn with a pleasant atmosphere that helps children be creative. The implementation of the utilization of goods ex (recycle) is to prepare the materials and tools that will be used to recycle the like paper hvs, glue, scissors in cycle 1 meeting 1 in the conduct of activities squeezed papers into shapes round / ball. In cycle 1 there are 2 meetings of tools and materials such as plastic bags, origami paper, glue, markers and scissors in the activity of making clothes from plastic bags. In cycle 2 meeting 1 tools and materials such as bags of plastic, paper origami, glue, scissors, and strap plastic in activities making bags of bags of plastic. In cycle 2 meeting 2 tools and materials such as bottles of plastic, scissors, paper origami and glue in the conduct of activities make pots of flowers. Learning cycle reset makes it easy for children to use the goods second-hand (recycle). In addition to recycle re- learning for children is very fun and interesting.

It can be seen from the observation Improving Attitudes Care Environment Through Pemafaatan Items Used (recycle) covers the second cycle. In the pre-cycle amounted to 39.58 $\%$, the first cycle as much as 2 meetings held at the first meeting with the average of $53.75 \%$, meeting for 2 in the first cycle seb e sar $62.08 \%$. After the recapitulation of the results of the actions in the first cycle, it was found that the average value in the first cycle was $57.92 \%$. Because in cycle I the child's environmental care attitude has not reached the target of $75 \%$, the researcher continues in cycle II at meeting 1, getting an average value of $73.33 \%$ at the second meeting in cycle II, the average value is $86.25 \%$. After the recapitulation of the results of the action in cycle II, it was found that the average value in cycle II was $79.79 \%$.

In cycle II, the increase in children's environmental care through the use of used goods (recycle) has increased quite significantly and is included in the Very High (VH) category. Then the researcher is considered complete and there is no need for the next cycle. From this description, it can be concluded that through the use of used goods (recycle) children in Class B Tk Arafah Rumbai Pesisir can improve children's environmental care. According to (Dasmo et al., 2015) which states that through the activities of play -based art craft that which from research is made goods are useful of goods secondhand or objects - objects of nature that exist in the around children that can boost the love of a child in the environment around. Besides 
that, things have also been described (Hanafi \& Sujarwo, 2015), which states that by using ingredients former creativity of children can be increased. In addition to the creativity of children are increasing, there is an increase in the understanding and skill in making tools permaianan instructive for learning in early childhood.

\section{CONCLUSION}

Based on the results of the study, it can be ignored that the proportion of increasing environmental awareness among children aged 5-6 years, the average number after data analysis of pre-cycle activities is in the Low category. Then in cycle one the average number is in the Medium category, and in cycle II the figure has reached the High category. Based on the research results, the teacher should use used materials to support children's learning and it is hoped that they can optimally support them.

\section{ACKNOWLEDGEMENT}

We are very grateful to the principal of Arafah Kindergarten for his willingness to be a research sample. Thank you also to Obsesi's Journal Manager for publishing the results of this research.

\section{REFERENCES}

Ahmad Susanto. (2011). Perkembangan anak usia dini. Jurnal Golden Age Hamzanwadi University.

Astini, B. N., -, N., Rachmayani, I., \& Suarta, I. N. (2017). Identifikasi Pemafaatan Alat Permaian Edukatif (Ape) Dalam Mengembangka Motorik Halus Anak Usia Dini. Jurnal Pendidikan Anak. https://doi.org/10.21831/jpa.v6i1.15678

Dasmo, D., Nurhayati, N., \& Marhento, G. (2015). Pengaruh Tingkat Pendidikan dan Pola Asuh Orangtua Terhadap Prestasi Belajar IPA. Formatif: Jurnal Ilmiah Pendidikan MIPA. https:/ / doi.org/10.30998/ formatif.v2i2.94

Depkes RI. (2018). Kementerian Kesehatan Republik Indonesia. Kementerian Kesehatan RI.

Depkes RI, \& RI, D. (2013). Peraturan Menteri Kesehatan Republik Indonesia Nomor 71 Tahun 2013 Tentang Pelayanan Kesehatan Pada Jaminan Kesehatan Nasional. In Peraturan Menteri Kesehatan. https:// doi.org/10.1007/s13398-014-0173-7.2

Hairiah, K., \& Suprayogo, D. (2008). Adaptasi Dan Mitigasi Pemanasan Global : Bisakah Agroforestri mengurangi resiko longsor dan emisi gas rumah kaca ? INAFE.

Hamzah, S. (2013). Pendidikan Lingkungan: Sekelumit Wawasan Pengantar. Bandung: Refika Aditama.

Hanafi, S. H., \& Sujarwo. (2015). Improving Children Creativity Through Recycling Media in TK Bima City. Jurnal Pendidikan Dan Pemberdayaan Masyarakat.

Ngah, R., \& Salleh, Z. (2015). Emotional Intelligence and Entrepreneurs' innovativeness towards Entrepreneurial Success: A Preliminary Study. American Journal of Economics. https://doi.org/10.5923/c.economics.201501.37

Purwanti, D. (2017). Pendidikan Karakter Peduli Lingkungan Dan Implementasinya. Dwija Cendekia: Jurnal Riset Pedagogik. https:/ / doi.org/10.20961/jdc.v1i2.17622

Purwanto, M. P. (2012). Metodologi Penelitian Kuantitatif untuk Psikologi dan Pendidikan. In Yogyakarta: Pustaka Pelajar.

Septianingsih, N., Asmawati, L., \& Sayekti, T. (2017). Meningkatkan Kreativitas Anak Usia 56 Tahun Melalui Media Bahan Bekas. Jurnal Penelitian Dan Pengembangan Pendidikan Anak Usia Dini. https:/ / doi.org/10.30870/jpppaud.v4i2.4653

Suharsimi, A. (2010). Prosedur Penelitian : Suatu Pendekatan Praktik (Edisi Revisi). In Rineka Cipta. https:// doi.org/10.1017/CBO9781107415324.004

Triwahyuni, T., Mustofa, F. L., \& Yusuf, M. (2016). Hubungan Faktor Individual dan Faktor Lingkungan Perumahan terhadap Kejadian Malaria di Desa Hanura Kecamatan Teluk 
Pandan Kabupaten Pesawaran Provinsi Lampung Tahun 2016. Jurnal Ilmu Kedokteran.

Wahyuni, S., \& Reswita, R. (2020). Pemahaman Guru mengenai Pendidikan Sosial Finansial pada Anak Usia Dini menggunakan Media Loose Parts. Jurnal Obsesi : Jurnal Pendidikan Anak Usia Dini. https:/ / doi.org/10.31004/obsesi.v4i2.493

Ahmad Susanto. (2011). Perkembangan anak usia dini. Jurnal Golden Age Hamzanwadi University.

Astini, B. N., -, N., Rachmayani, I., \& Suarta, I. N. (2017). Identifikasi Pemafaatan Alat Permaian Edukatif (Ape) Dalam Mengembangka Motorik Halus Anak Usia Dini. Jurnal Pendidikan Anak. https:// doi.org/10.21831/jpa.v6i1.15678

Dasmo, D., Nurhayati, N., \& Marhento, G. (2015). Pengaruh Tingkat Pendidikan dan Pola Asuh Orangtua Terhadap Prestasi Belajar IPA. Formatif: Jurnal Ilmiah Pendidikan MIPA. https:// doi.org/10.30998/formatif.v2i2.94

Depkes RI. (2018). Kementerian Kesehatan Republik Indonesia. Kementerian Kesehatan RI.

Depkes RI, \& RI, D. (2013). Peraturan Menteri Kesehatan Republik Indonesia Nomor 71 Tahun 2013 Tentang Pelayanan Kesehatan Pada Jaminan Kesehatan Nasional. In Peraturan Menteri Kesehatan. https:/ / doi.org/10.1007/s13398-014-0173-7.2

Hairiah, K., \& Suprayogo, D. (2008). Adaptasi Dan Mitigasi Pemanasan Global: Bisakah Agroforestri mengurangi resiko longsor dan emisi gas rumah kaca? INAFE.

Hamzah, S. (2013). Pendidikan Lingkungan: Sekelumit Wawasan Pengantar. Bandung: Refika Aditama.

Hanafi, S. H., \& Sujarwo. (2015). Improving Children Creativity Through Recycling Media in TK Bima City. Jurnal Pendidikan Dan Pemberdayaan Masyarakat.

Ngah, R., \& Salleh, Z. (2015). Emotional Intelligence and Entrepreneurs' innovativeness towards Entrepreneurial Success: A Preliminary Study. American Journal of Economics. https:// doi.org/10.5923/c.economics.201501.37

Purwanti, D. (2017). Pendidikan Karakter Peduli Lingkungan Dan Implementasinya. Dwija Cendekia: Jurnal Riset Pedagogik. https:// doi.org/10.20961/jdc.v1i2.17622

Purwanto, M. P. (2012). Metodologi Penelitian Kuantitatif untuk Psikologi dan Pendidikan. In Yogyakarta: Pustaka Pelajar.

Septianingsih, N., Asmawati, L., \& Sayekti, T. (2017). Meningkatkan Kreativitas Anak Usia 56 Tahun Melalui Media Bahan Bekas. Jurnal Penelitian Dan Pengembangan Pendidikan Anak Usia Dini. https:/ / doi.org/10.30870/jpppaud.v4i2.4653

Suharsimi, A. (2010). Prosedur Penelitian : Suatu Pendekatan Praktik (Edisi Revisi). In Rineka Cipta. https:/ / doi.org/10.1017/CBO9781107415324.004

Triwahyuni, T., Mustofa, F. L., \& Yusuf, M. (2016). Hubungan Faktor Individual dan Faktor Lingkungan Perumahan terhadap Kejadian Malaria di Desa Hanura Kecamatan Teluk Pandan Kabupaten Pesawaran Provinsi Lampung Tahun 2016. Jurnal Ilmu Kedokteran.

Wahyuni, S., \& Reswita, R. (2020). Pemahaman Guru mengenai Pendidikan Sosial Finansial pada Anak Usia Dini menggunakan Media Loose Parts. Jurnal Obsesi : Jurnal Pendidikan Anak Usia Dini. https:/ / doi.org/10.31004/obsesi.v4i2.493 